Journal of Business and Management Studies (JBMS)

ISSN: $2709-0876$

DOI: 10.32996/jbms

Journal Homepage: www.al-kindipublisher.com/index.php/jbms

\title{
Perceived Risk of Covid-19 and Trust on m-Health Transaction Intention
}

\author{
Fauzia Nur Laili ${ }^{1} \square$ and Lilik Wahyudi ${ }^{2}$ \\ ${ }^{12}$ Faculty of Economics and Business, Sebelas Maret University, Indonesia \\ $\square$ Corresponding Author: Fauzia Nur Laili, E-mail: laili_mm2019@student.mail.uns.ac.id
}

\section{ARTICLE INFORMATION}

Received: 08 October 2021

Accepted: 02 November 2021

Published: 28 November 2021

DOI: $10.32996 / j b m s .2021 .3 .2 .24$

\section{KEYWORDS}

Trust, m-Health, Transaction intention, Perceived risk of COVID19

\section{ABSTRACT}

The purpose of the study is to determine the impact of trust antecedents on the intent of transactions in mHealth applications. The antecedents of trust included perceived ease of use, perceived usefulness, perceived quality, perceived safety, and perceived Covid 19 risks. Perceived risks of COVID19 were also examined for moderating effects on the relationship between trust and $\mathrm{m}$-Health transaction intention. The study used a quantitative method with a survey approach. Our surveys are distributed online via the Lime Survey app. 253 respondents responded to the questionnaire according to the criteria. Results showed that the antecedents that had a significant impact on trust were perceived usefulness ( $P=0.012)$, perceived quality $(P=0.002)$, and perceived safety $(P=0.000)$. On the other hand, the perceived ease of use $(P=0.566)$ and the perceived risk $(P=0.871)$ did not significantly affect trust. Trust $(P=0.000)$ and perceived risks of COVID19 $(P=0.011)$ directly affect $m$-Health transaction intention. The study also found that the perceived risk of COVID19 did not impact the consumer trust in $\mathrm{m}$-Health but directly impacted transaction intention.

\section{Introduction}

Mobile Health ( $\mathrm{m}$-Health) is a digital platform for health products and services. Benefits of the $\mathrm{m}$-Health application offered to consumers include a wide range of services, low prices, and easier access to medical services. The m-Health component focuses not only on technology but also on infrastructure, healthcare facilities, and healthcare professionals. The benefits of $\mathrm{m}$-Health are more and more felt during the COVID 19 pandemic after the government has advised the public to avoid public facilities such as hospitals.

Trust is an important aspect that researchers and e-commerce executives need to investigate in order to build loyalty when shopping and selling online (Zhao, Huang, \& Su, 2019). According to (Abbes, Hallem, \& Taga, 2020)), trust can influence potential consumers in their stores. Potential consumers try to make trust in sellers by looking at the various things considered in this study, including perceived ease of use, perceived usefulness, perceived safety, and perceived quality, and perceived risk COVID 19. Therefore, we examine the five perceptions as independent variables, trust as a mediator, and the m-Health transaction intention as a dependent variable.

Previous research by (Marakanon \& Panjakajornsak, 2017) showed that consumers' perceptions of low risk can significantly increase their trust in sellers. Consumers will trust the seller if the risk they believe is low. In this study, in addition to perceived risk, it was also shown that perceived quality significantly increases consumer trust in the seller. Therefore, it can be concluded that the better the quality perception of potential consumers towards the e-commerce platform, the higher their trust in the platform.

Public trust in digital products is underpinned by several factors. One of the most popular theories in the world of technology and management is the Technology Acceptance Model (TAM). The pioneers of this theory can undermine trust in mHealth applications. According to (Sezgin, Özkan-Yildirim, \& Yildirim, 2018), TAM's pioneers are perceived ease of use and perceived usefulness. (Y. Kim \& Peterson, 2017) add perceived security as an antecedent of trust when buying and selling on websites online.

Copyright: (C) 2021 the Author(s). This article is an open access article distributed under the terms and conditions of the Creative Commons Attribution (CC-BY) 4.0 license (https://creativecommons.org/licenses/by/4.0/). Published by Al-Kindi Centre for Research and Development, London, United Kingdom. 
The antecedents of trust in e-commerce consist of five components: quality, risk, technology acceptance, personality, and mobility (Sarkar, Chauhan, \& Khare, 2020). During this pandemic, consumers think about leaving home (recreation) can be categorized as a risk (Rather, 2021). The perceived risk associated with consumer fear of COVID 19 is a new indicator for completing Sarkar's study. According to Addo, Jiaming, Kulbo, \& Liangqiang (2020), consumer fears about the illness caused by COVID19 have a positive impact on the intention to buy personal protective equipment.

Some previous studies on COVID19 perceived risk maybe support the relationship between tourist destination reputation, tourist destination CSR, perceived trust, and tourists' revisit intentions (Hassan \& Soliman, 2021). The perceived risk of COVID19 also has a moderation impact on the relationship between social media and CBE (Customer Brand Engagement), the relationship between CBE and return intentions, and the relationship between CBE and BCC (Brand Cocreation) (Rather, 2021).

\section{Conceptual Framework and hypothesis development \\ 2.1 Perceived ease of use \& Perceived usefulness}

Trust is a variable with various antecedents and consequences in consumer behavior theory. In a study Khan, Umer, Umer, \& Naqvi (2021) tested public trust in the Pakistani government's social media account services. He found that ease of use and perceived usefulness were antecedents of trust. (Sarkar et al., 2020) have researched a meta-analytic paper discussing the antecedents of trust. The variables are the perceived ease of use and the perceived usefulness that affect aspects of technology acceptance theory.

Perceived ease of use and perceived usefulness combined with two perceived risks (security and privacy) impacts initial trust in the use of self-driving cars (Zhang et al., 2019). Corritore, Marble, Wiedenbeck, Kracher, \& Chandran (2005) conducted an experimental study to measure user trust on two websites using three perceptions: perceived reliability, perceived usability, and perceived risk. The results show that perceived ease of use can affect user trust in the website. Therefore, a hypothesis can be derived from some of the above explanations.

H1: Perceived ease of use has a positive effect on trust in $\mathrm{m}$-Health applications

H2: Perceived usefulness has a positive effect on public trust in $\mathrm{m}$-Health applications

\subsection{Perceived security}

A previous study (J. Kim, Jin, \& Swinney, 2009) categorized security and data protection factors as aspects of e-commerce quality that have a positive impact on consumer trust in online transactions. Perceived security is also included in the financial security aspect of the electronic services of web transactions (Harris \& Goode, 2010). Thaichon, Lobo, Prentice, \& Quach (2014) explains that the quality of online services can be divided into four aspects: network quality, customer service and technical support, information quality, and data protection. These four aspects have a positive impact on consumer trust in your website. Perceived security can directly affect consumer trust in e-commerce. The following hypothesis can be made.

H3: Perceived Security has a positive effect on consumer trust in $\mathrm{m}$-Health applications.

\subsection{Perceived quality}

Perceived quality and perceived risk have a direct impact on consumer trust (Marakanon \& Panjakajornsak, 2017). Earlier research on organic brands (Konuk, 2018) shows that perceived (food) quality has a significant positive impact on consumer trust. (Harris \& Goode, 2004, 2010; Thaichon et al., 2014) explained that the quality of service has a positive impact on consumer trust in the platform.

Luo, Wang, Zhang, Niu, \& Tu (2020) found a positive effect on e-commerce quality to online consumer trust. The quality aspects are system quality, security assurance, product diversity, and after-sales service. The perceived quality (Chi, 2018) is an aspect of perceived benefits, which is one of the variables of technology acceptance theory. The following hypothesis can be derived.

H4: Perceived quality has a positive impact on consumer trust in $\mathrm{m}$-Health applications

\subsection{Perceived risk of COVID-19}

A study of e-commerce (Young Kim \& Kim, 2004) found a negative impact between perceived risk and trust. The lower the risk, the higher the trust in the e-commerce platform. In this study, the risk of COVID 19 means consumers fear activities outside the home. Patients who are afraid of medical examinations in medical facilities such as pharmacies, clinics, and hospitals. (Bae $\&$ Chang, 2021) divides COVID19's perception of risk into two aspects: cognitive and emotional. The perceived risk of COVID19 (cognitive) has a positive impact on the intention of tourists visiting non-tactical tourism, while the emotional side has a negative impact. In addition to the tourism context, the perceived risk of COVID 19 also influences purchasing behavior in purchasing personal protective equipment. The higher the risk/fear of Covid19, the higher intention to purchase (Addo et al., 2020) 
(Alam, Alam, Rahman, \& Taghizadeh, 2021) wrote perceived risk of COVID19 as SQ (self-quarantine) to avoid public areas. His research results show that SQ supports the relationship between behavioral intention to use mHealth applications in Bangladesh. Another study conducted by (Rather, 2021) found that perceived risk and fear of COVID19 during pandemic could decrease effects of CBE (Customer Brand Engagement) to revisit in tourism destinations. Hassan \& Soliman (2021) also investigated the moderation effect of tourists in Egypt on the relationship between trust in travel agencies and willingness to revisit. Therefore, the hypothesis can be derived from some of the above statements.

H5: Perceived risk of COVID19 has a positive impact on consumer trust in m-Health applications.

H6: Perceived risk of COVID19 has a positive impact on consumer m-Health transaction intention.

H7: Perceived risk of COVID19 moderates the relationships between trust and $\mathrm{m}$-Health transaction intention.

\subsection{Trust and $\boldsymbol{m}$-Health transaction intention}

$\mathrm{m}$-Health transaction intention is a consistent consumption behavior in marketing. The study assumes that trust influences $\mathrm{m}$ Health transaction intention. The purchase intention is such potential consumers want to buy in online stores (Pavlou, 2003). An indicator of success in e-commerce can be read from how strongly consumers are trying to act. The implications of this study are the intention of performing online transactions in e-commerce (He, Lu, \& Zhou, 2008). Consumer trust can reduce the uncertainty of transactions on websites, so many studies have shown that the outcome of trust is behavioral intention (Khan et al., 2021; Sarkar et al., 2020; Wang, Ngamsiriudom, \& Hsieh, 2015). A hypothesis based on some of the above statements.

H8: Trust in the mHealth application has a positive impact on transaction intention

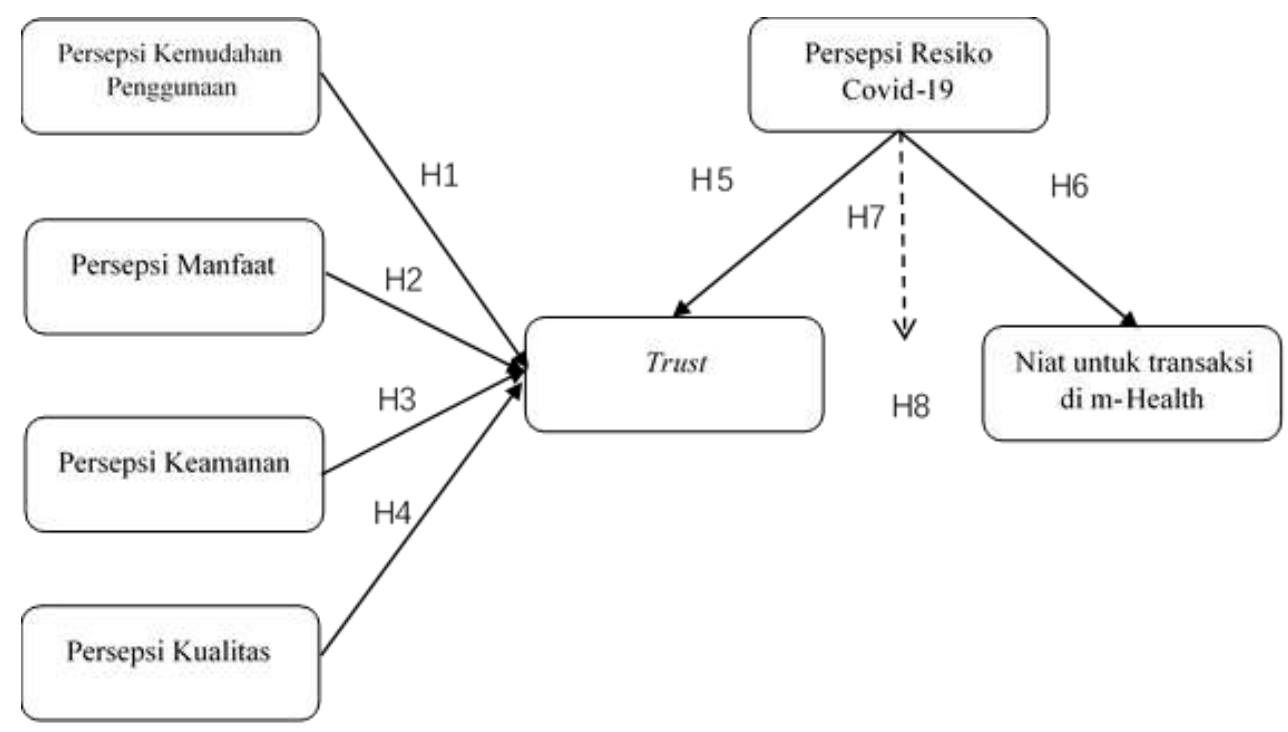

Figure 1 Conceptual framework

\section{Materials and Methods}

This research is quantitative with a survey approach. According to (Cooper \& Schindler, 2014) the development of the internet is very helpful for researchers in conducting surveys. Sources of data were taken from questionnaires distributed online to the research object. The application for preparing the questionnaire used Lime Survey. Questionnaires were distributed using social media Whatsapp via private chat or groups. The number of respondents who met the criteria was 253 people from a total of 311 complete questionnaires.

Data were analyzed using Partial Least Squares Structural Equation Model (PLS-SEM) method to evaluate the measurement and structure of the model (Hair, Ringle, \& Sarstedt, 2011). Sarstedt, Ringle, \& Hair, (2020) said that PLS-SEM has become a popular method used in complex research models with latent variables and relationships between variables. This study uses a measurement scale that uses 5 Likert scales with $1=$ strongly disagree, $2=$ disagree, $3=$ neutral, $4=$ agree and $5=$ strongly agree. The Likert scale is a scale developed by Rensis Likert which is the most frequently used scale of the summated rating scales (Cooper \& Schindler, 2014). 


\section{Results and Analysis}

The data was collected using an online survey (Lime Survey). 331 respondents answered the question completely. Then we filtered the data and the remaining 253 respondents could be used as survey data. The complete respondent profile is in the table below.

Table 1

Respondents' characteristics

\begin{tabular}{|c|c|c|}
\hline Description & Keterangan & Persentase \\
\hline \multirow[t]{2}{*}{ Gender } & Men & $32,20 \%$ \\
\hline & Women & $66,80 \%$ \\
\hline \multirow[t]{3}{*}{ Age } & $15-25$ years old & $13,04 \%$ \\
\hline & 26-40 years old & $63,64 \%$ \\
\hline & Above 40 years old & $23,32 \%$ \\
\hline \multirow{2}{*}{ Location } & Soloraya & $55,73 \%$ \\
\hline & Outside & $44,27 \%$ \\
\hline \multirow{4}{*}{ Smartphone user experience } & $<1$ year & $3,56 \%$ \\
\hline & $1-5$ years & $13,04 \%$ \\
\hline & 6-10 years & $39,53 \%$ \\
\hline & $>10$ years & $43,87 \%$ \\
\hline \multirow[t]{7}{*}{ Education } & Junior High School & $0,79 \%$ \\
\hline & Senior High School & $10,28 \%$ \\
\hline & Diploma (D3) & $7,51 \%$ \\
\hline & Bachelor (S1) & $52,57 \%$ \\
\hline & Postgraduate (S2) & $25,69 \%$ \\
\hline & Doctoral (S3) & $1,19 \%$ \\
\hline & others & $1,98 \%$ \\
\hline \multirow[t]{5}{*}{ Income } & $<2.500 .000$ & $26,09 \%$ \\
\hline & $2.500 .000-5.000 .000$ & $40,32 \%$ \\
\hline & $5.000 .000-7.500 .000$ & $14,23 \%$ \\
\hline & $7.500 .000-10.000 .000$ & $9,88 \%$ \\
\hline & $>10.000 .000$ & $9,49 \%$ \\
\hline
\end{tabular}

The table above shows that the respondents of this survey were divided into two groups: male and female. The number of male respondents was 84 (33\%) and that of females was 169 (67\%). There are more women than men. The majority of respondents in this survey are $26-40$ years old is 161 respondents (63.64\%). In addition, the second largest age group (over 40 years old) is 59 respondents (23.32\%), and the third group is 33 respondents (13.04\%) 15-25 years old.

The number of respondents who live in Solo and its surroundings is more than those who live outside Soloraya. The number of respondents who live in Soloraya is 141 respondents (55.73\%) and those who live outside Soloraya are 112 respondents (44.27\%). Based on the table, the respondents of this study have several using experience with smartphones. The number of respondents who have more than 10 years of experience is 111 respondents (43.87\%), 6-10 years is 100 respondents (39.53\%), 1-5 years are 33 people (13.04\%) and less than one year there are only 9 respondents (3.56\%).

\subsection{Measurement model assessment}

Data analysis begins with testing the measurement model and continues with testing the structural model. The results of the construction model test are shown in Table 2 below. The outer model measures the indicators of research. The latent variable measurement model in this study is the reflection measurement model that variables are correlated and exchangeable, based on the reliability and validity of the indicators. Outer loading is the basis of indicator reliability. The outer loading value required in the theoretical test is 0.7 , if it is less than 0.7 we should erase it. This study was two indicator variables with an outer loading less than 0.7: Perceived security (PS4 $=0.440$ ) and transaction intention (ITT4 = 0.329).

Table 2

Reliability and validity of measurable items 


\begin{tabular}{|c|c|c|c|c|c|}
\hline Construct & Item & $\begin{array}{l}\text { Factor } \\
\text { Loading }\end{array}$ & Cronbach Alpha & $\begin{array}{l}\text { Composite } \\
\text { Reliability }\end{array}$ & AVE \\
\hline \multirow{4}{*}{$\begin{array}{l}\text { Intention to } \\
\text { transact }\end{array}$} & ITT[ITT1] & 0,898 & 0,914 & 0,946 & 0,854 \\
\hline & ITT[ITT2] & 0,925 & & & \\
\hline & ITT[ITT3] & 0,915 & & & \\
\hline & ITT[ITT4] & 0,440 & & & \\
\hline \multirow{4}{*}{$\begin{array}{l}\text { Perceived Ease } \\
\text { of Use }\end{array}$} & PEOU[PEOU1] & 0,845 & 0,904 & 0,933 & 0,777 \\
\hline & PEOU[PEOU2] & 0,889 & & & \\
\hline & PEOU[PEOU3] & 0,900 & & & \\
\hline & PEOU[PEOU4] & 0,890 & & & \\
\hline \multirow{3}{*}{$\begin{array}{l}\text { Perceived } \\
\text { Quality }\end{array}$} & $P Q[P Q 1]$ & 0,889 & 0,897 & 0,936 & 0,829 \\
\hline & $P Q[P Q 2]$ & 0,923 & & & \\
\hline & $P Q[P Q 3]$ & 0,919 & & & \\
\hline \multirow{5}{*}{$\begin{array}{l}\text { Perceived } \\
\text { Security }\end{array}$} & PS[PS1] & 0,890 & 0,880 & 0,917 & 0,735 \\
\hline & PS[PS2] & 0,830 & & & \\
\hline & PS[PS3] & 0,870 & & & \\
\hline & PS[PS4] & 0,329 & & & \\
\hline & $\mathrm{PS}[\mathrm{PS} 5]$ & 0,827 & & & \\
\hline \multirow{4}{*}{$\begin{array}{l}\text { Perceived } \\
\text { Usefulness }\end{array}$} & PU[PU1] & 0,854 & 0,873 & 0,913 & 0,724 \\
\hline & PU[PU2] & 0,856 & & & \\
\hline & PU[PU3] & 0,825 & & & \\
\hline & PU[PU4] & 0,870 & & & \\
\hline \multirow{3}{*}{$\begin{array}{l}\text { Perceived Risk } \\
\text { of COVID19 }\end{array}$} & RISK[RISK1] & 0,935 & 0,905 & 0,940 & 0,839 \\
\hline & RISK[RISK2] & 0,883 & & & \\
\hline & RISK[RISK3] & 0,929 & & & \\
\hline \multirow[t]{3}{*}{ Trust } & TRUST[TRUST1] & 0,891 & 0,867 & 0,919 & 0,790 \\
\hline & TRUST[TRUST2] & 0,901 & & & \\
\hline & TRUST[TRUST3] & 0,874 & & & \\
\hline
\end{tabular}

After ITT4 and PS4 were eliminated, Cronbach alpha, composite reliability, and AVE tests showed results above $>0.7$. This shows that the criteria for the measurement model are good. Furthermore, discriminant validity was tested using the Fornell-Larcker criteria. The test results can be seen in the following table;

Table 3

Fornell Larcker Criterion

\begin{tabular}{|l|l|l|l|l|l|l|l|}
\hline & ITT & PEOU & PQ & PU & RISK & PS & Trust \\
\hline
\end{tabular}




\begin{tabular}{|l|l|l|l|l|l|l|l|}
\hline ITT & $\mathbf{0 , 9 2 4}$ & & & & & & \\
\hline PEOU & 0,256 & $\mathbf{0 , 8 8 1}$ & & & & & \\
\hline PQ & 0,389 & 0,486 & $\mathbf{0 , 9 1 0}$ & & & & \\
\hline PU & 0,542 & 0,637 & 0,598 & $\mathbf{0 , 8 5 1}$ & & & \\
\hline RISK & 0,296 & 0,427 & 0,319 & 0,497 & $\mathbf{0 , 9 1 6}$ & & \\
\hline PS & 0,460 & 0,558 & 0,708 & 0,601 & 0,349 & $\mathbf{0 , 8 5 7}$ & \\
\hline Trust & 0,490 & 0,512 & 0,671 & 0,611 & 0,342 & 0,732 & $\mathbf{0 , 8 8 9}$ \\
\hline
\end{tabular}

\subsection{Structural Model Evaluation}

The process of testing the structural model run until getting the required criteria. Improvements are made if there are problems in the measurement model. The existing test results show that all of the measurement model testing criteria are good. The process is continued by testing the relationship between variables using a standard $95 \%$ confidence level with a t value of 1.96 . The results of complete hypothesis testing can be seen in the following table:

Table 4

Structural model results

\begin{tabular}{|l|l|l|l|l|l|l|}
\hline Hypothesis & $\begin{array}{l}\text { Original } \\
\text { Sample } \\
(\mathrm{O})\end{array}$ & $\begin{array}{l}\text { Sample } \\
\text { Mean } \\
(\mathrm{M})\end{array}$ & $\begin{array}{l}\text { Standard } \\
\text { Deviation } \\
\text { (STDEV) }\end{array}$ & $\begin{array}{l}\text { T Statistics } \\
(|\mathrm{O} / \mathrm{STDEV}|)\end{array}$ & P.Values & Keterangan \\
\hline Perceived Ease of Use -> Trust (H1) & 0,035 & 0,040 & 0,060 & 0,574 & $\mathbf{0 , 5 6 6}$ & $\begin{array}{l}\text { not } \\
\text { supported }\end{array}$ \\
\hline Perceived Usefulness -> Trust (H2) & 0,183 & 0,181 & 0,073 & 2,508 & 0,012 & supported \\
\hline $\begin{array}{l}\text { Perceived Security -> Trust (H3) } \\
\text { Perceived Quality -> Trust (H4) }\end{array}$ & 0,433 & 0,434 & 0,061 & 7,144 & 0,000 & supported \\
\hline $\begin{array}{l}\text { Perceived Risk of COVID 19 -> } \\
\text { Trust (H5) }\end{array}$ & 0,010 & 0,010 & 0,063 & 0,162 & $\mathbf{0 , 8 7 1}$ & supported \\
\hline $\begin{array}{l}\text { Perceived Risk of COVID 19 -> m- } \\
\text { Health Transaction Intention (H6) }\end{array}$ & 0,163 & 0,165 & 0,064 & 2,560 & 0,011 & supported \\
\hline $\begin{array}{l}\text { Trust -> m-Health Transaction } \\
\text { Intention (H8) }\end{array}$ & 0,432 & 0,431 & 0,055 & 7,831 & 0,000 & supported \\
\hline
\end{tabular}




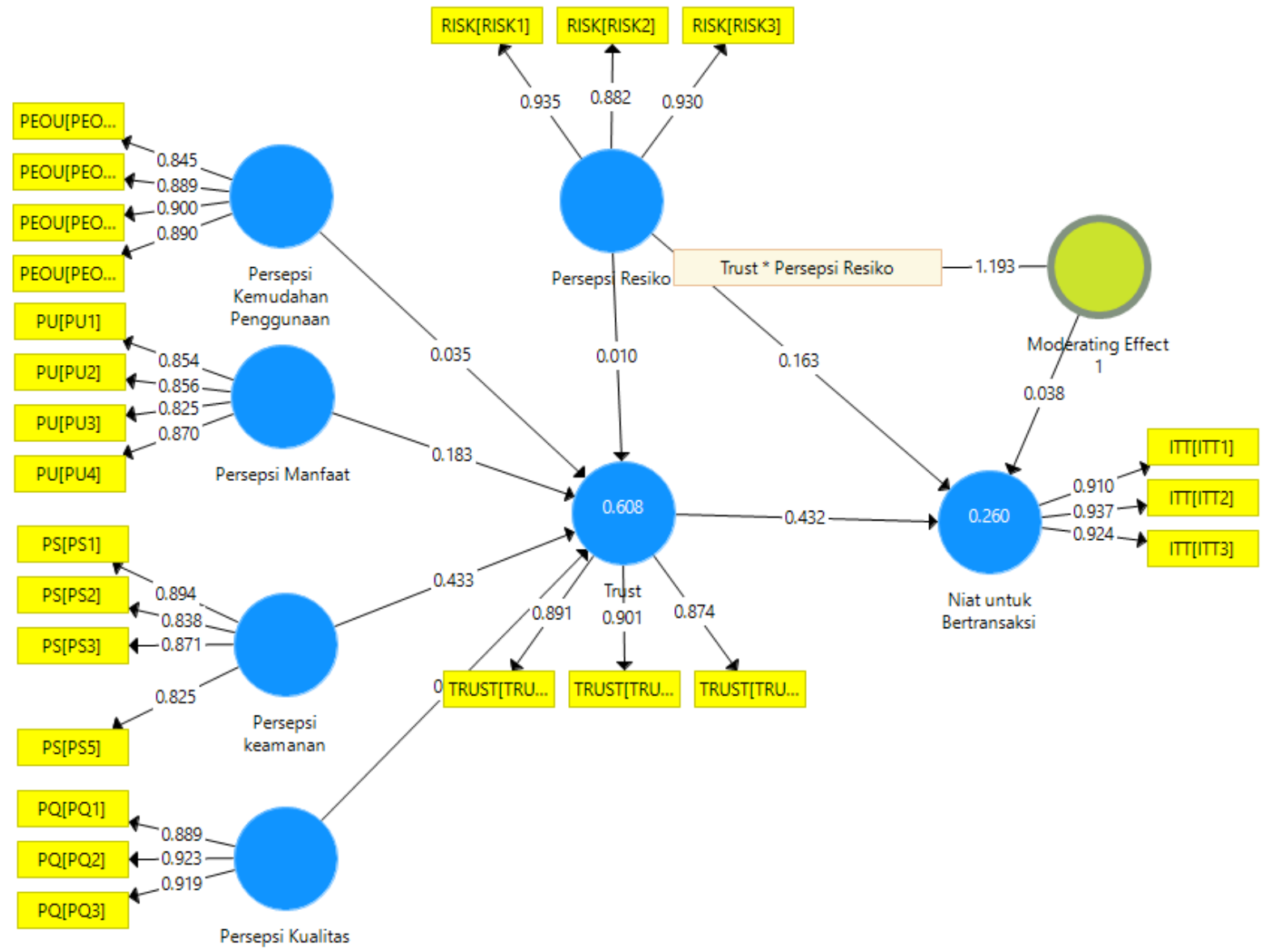

Figure 2. Structural Model

The structural model was analyzed using the criteria suggested by Henseler et al. (2016, pp. 207-231) namely Standardized Root Mean Square Residual (SRMR). SRMR is a measure of the mean absolute value of the residual covariance. Its mechanism of action is based on the transformation of the sample matrix and predicted matrix into a correlation matrix. SRMR is defined as the difference between the observed correlation and the correlation matrix in the model. Henseler et al. (2014) introduced SRMR as a measurement of goodness of fit for PLS-SEM which can be used to avoid model specification errors. An SRMR value of less than 0.10 was considered an acceptable model fit. In addition, the predictive power of the model was examined using the R2 and Q2 values of all predicted variables. SRMR value of this study is less than 0.10 . It means the goodness of fit of this structural model is accepted (Table 5).

Table 5

Standardized Root Mean Square Residual (SRMR)

\begin{tabular}{|l|l|l|}
\hline & Saturated Model & Estimated Model \\
\hline SRMR & 0,050 & 0,061 \\
\hline d_ULS & 0,753 & 1,109 \\
\hline d_G & 0,480 & 0,515 \\
\hline Chi-Square & 734,569 & 770,849 \\
\hline NFI & 0,848 & 0,840 \\
\hline
\end{tabular}


Table 6

Mediation Effect

\begin{tabular}{|l|l|l|l|l|l|l|}
\hline & $\begin{array}{l}\text { Original } \\
\text { Sample } \\
(\mathrm{O})\end{array}$ & $\begin{array}{l}\text { Sample } \\
\text { Mean (M) }\end{array}$ & $\begin{array}{l}\text { Standard } \\
\text { Deviation } \\
\text { (STDEV) }\end{array}$ & T Stat & P Values & Conclusion \\
\hline PEOU -> Trust - > ITT & 0,015 & 0,017 & 0,026 & 0,575 & $\mathbf{0 , 5 6 5}$ & $\begin{array}{l}\text { not } \\
\text { supported }\end{array}$ \\
\hline PQ -> Trust -> ITT & 0,102 & 0,101 & 0,034 & 2,958 & 0,003 & supported \\
\hline PU -> Trust -> ITT & 0,079 & 0,078 & 0,035 & 2,283 & 0,022 & supported \\
\hline RISK -> Trust - > ITT & 0,004 & 0,004 & 0,028 & 0,161 & $\mathbf{0 , 8 7 2}$ & $\begin{array}{l}\text { not } \\
\text { supported }\end{array}$ \\
\hline PS -> Trust -> ITT & 0,187 & 0,187 & 0,037 & 5,094 & 0,000 & supported \\
\hline
\end{tabular}

Table 7

Moderation Effect

\begin{tabular}{|l|l|l|l|l|l|l|l|}
\hline & $\begin{array}{l}\text { Original } \\
\text { Sample } \\
(\mathrm{O})\end{array}$ & $\begin{array}{l}\text { Sample } \\
\text { Mean } \\
(\mathrm{M})\end{array}$ & $\begin{array}{l}\text { Standard } \\
\text { Deviation } \\
\text { (STDEV) }\end{array}$ & T Stat & P Values & Conclusion & Moderation \\
\hline $\begin{array}{l}\text { Moderating Effect 1 Trust } \\
->\text { Transaction Intention }\end{array}$ & 0,038 & 0,041 & 0,053 & 0,717 & $\mathbf{0 , 4 7 4}$ & $\begin{array}{l}\text { not } \\
\text { supported }\end{array}$ & No \\
\hline
\end{tabular}

\section{Discussion}

Data were analyzed using the Partial Least Squares Structural Equation Model (PLS-SEM) method to measure and evaluate the model structure (Hair et al., 2011). PLS-SEM has become a popular method that is often used in research models with complex relationships/variables (Sarstedt et al., 2020). PLS-SEM is more flexible than others in terms of data requirements and specification of the relationship between model and indicator variables. Researchers use the Smart PLS 3 application because this application is easy to use to analyze multivariate research data.

The results of the model measurement test as shown in table 4 show that the perceived ease of use variable does not significantly affect consumer trust in the $\mathrm{m}$-Health application, this is not the same as the results of Sarkar et al research on perceived ease of use as one of the antecedents of consumer confidence. Likewise, according to (Corritore et al., 2005), the perception of the ease of use of the website affects user trust.

In the theory of technology acceptance or what is often called TAM, perceived ease of use and perceived usefulness were the main antecedents as research conducted by Sarkar et al. In this study, the relationship between perceived usefulness and consumer trust was significant. It shows that the result of this study is like previous research conducted by Sarkar and Zhang (Sarkar et al., 2020; Zhang et al., 2019).

Based on research, according to a (Harris \& Goode, 2010)study, the relationship between perceived security and consumer trust has a significant impact. Harris investigated the impact of perceived security on e-trust transactions through websites. Perceived safety can affect consumer trust in e-commerce (Cui, Lin, \& Qu, 2018).

The quality of the platform is especially appealing to consumers. According to Luo et al., (2020), perceived quality has a positive impact on online consumer trust. The results of this study show that perceived quality has a significant impact on consumer trust in mHealth. This corresponds study (Marakanon \& Panjakajornsak, 2017) that perceived quality has a positive impact on consumer trust, either directly or mediated by perceived risk.

In this study, the perception of COVID19 risk did not significantly affect consumer trust, but it significantly affected the intent of the transaction. Awareness of high COVID 19 risk leads consumers to access high medical services and is also studied by (Addo et al., 2020), they investigated increased buying behavior of personal protective equipment when consumers were also at high risk/fear of the Covid19 virus. However, the results of this study also explain that the perception of the risk of COVID 19 did not significantly affect consumer trust. 
According to (Rather, 2021) survey, COVID19's perception of risk has a moderation impact on the relationship between customer brand engagement with a brand and the intent to visit a tourist attraction(Alam et al., 2021) also found that awareness of COVID19 risk had a moderate impact on the relationship between behavioral intention and use mHealth application in Bangladesh. The results of this study are inconsistent with previous studies in which risk perception does not moderate effect on the relationship between mHealth trust and transaction intention.

Regarding consumer behavior in e-commerce, according to (He et al., 2008), an indicator of e-commerce success can be seen in the consumer's intention to act in the mHealth application. In some studies, the risk is always related to trust. However, the risk seems to deny trust in the seller (application). This may be related to changes in consumer behavior during this pandemic, which is a panic buying that leads people to buy something immediately, without worrying about the seller's reputation (trust in seller).

\section{Conclusion}

Several factors affect consumer trust in mHealth applications. The results of this study show that the factors that significantly impact trust are perceived usefulness, perceived quality, and perceived security. The perceived ease of use did not significantly affect trust, and the perceived risk of COVID19 was not significant. However, risk awareness has a significant impact on m-Health's transaction intention.

The limitations of this research were first, due to the location of the respondents, we could only divide the respondents into two groups, Soloraya and non-Soloraya, and future studies should expand respondents based on location more than two groups. Second, the results of this study show that perceived ease of use and perceived risk of COVID19 do not have a significant impact on consumer trust, so they can be tested on a larger range of respondents for future surveys. Third, the moderation of the perceived risk of COVID19 on the relationship between trust and transaction intention was no effect. Other variables should be used for further research to moderate ex accessibility and customer review.

\section{References}

[1] Abbes, I., Hallem, Y., \& Taga, N. (2020). Second-hand shopping and brand loyalty: The role of online collaborative redistribution platforms. Journal of Retailing and Consumer Services, 52(April 2019), 101885. https://doi.org/10.1016/j.jretconser.2019.101885

[2] Addo, P. C., Jiaming, F., Kulbo, N. B., \& Liangqiang, L. (2020). COVID-19: fear appeal favoring purchase behavior towards personal protective equipment. Service Industries Journal, 40(7-8), 471-490. https://doi.org/10.1080/02642069.2020.1751823

[3] Alam, M. M. D., Alam, M. Z., Rahman, S. A., \& Taghizadeh, S. K. (2021). Factors influencing m-Health adoption and its impact on mental wellbeing during COVID-19 pandemic: A SEM-ANN approach. Journal of Biomedical Informatics, 116(January), 103722. https://doi.org/10.1016/j.jbi.2021.103722

[4] Bae, S. Y., \& Chang, P. J. (2021). The effect of coronavirus disease-19 (COVID-19) risk perception on behavioral intention towards 'untact' tourism in South Korea during the first wave of the pandemic (March 2020). Current Issues in Tourism, 24(7), 1017-1035. https://doi.org/10.1080/13683500.2020.1798895

[5] Chi, T. (2018). Journal of Retailing and Consumer Services Understanding Chinese consumer adoption of apparel mobile commerce: An extended TAM approach. Journal of Retailing and Consumer Services, 44(July), 274-284. https://doi.org/10.1016/j.jretconser.2018.07.019

[6] Cooper, D. R., \& Schindler, P. S. (2014). Business Research Methods 12th Edition. In Business Research Methods.

[7] Corritore, C. L., Marble, R. P., Wiedenbeck, S., Kracher, B., \& Chandran, A. (2005). Measuring online trust of websites: Credibility, perceived ease of use, and risk. Association for Information Systems - 11th Americas Conference on Information Systems, AMCIS 2005: A Conference on a Human Scale, 5, 2298-2306.

[8] Cui, F., Lin, D., \& Qu, H. (2018). The impact of perceived security and consumer innovativeness on e-loyalty in online travel shopping. Journal of Travel and Tourism Marketing, 35(6), 819-834. https://doi.org/10.1080/10548408.2017.1422452

[9] Hair, J. F., Ringle, C. M., \& Sarstedt, M. (2011). PLS-SEM: Indeed a silver bullet. Journal of Marketing Theory and Practice, 19(2), 139-152. https://doi.org/10.2753/MTP1069-6679190202

[10] Harris, L. C., \& Goode, M. M. H. (2004). The four levels of loyalty and the pivotal role of trust: A study of online service dynamics. Journal of Retailing, 80(2), 139-158. https://doi.org/10.1016/j.jretai.2004.04.002

[11] Harris, L. C., \& Goode, M. M. H. (2010). Online servicescapes, trust, and purchase intentions. Journal of Services Marketing, 24(3), $230-243$. https://doi.org/10.1108/08876041011040631

[12] Hassan, S. B., \& Soliman, M. (2021). COVID-19 and repeat visitation: Assessing the role of destination social responsibility, destination reputation, holidaymakers' trust, and fear arousal. Journal of Destination Marketing and Management, 19(May 2020), 100495. https://doi.org/10.1016/j.jdmm.2020.100495

[13] He, D., Lu, Y., \& Zhou, D. (2008). Empirical Study of Consumers' Purchase Intentions in C2C Electronic Commerce. Tsinghua Science and Technology, 13(3), 287-292. https://doi.org/10.1016/S1007-0214(08)70046-4

[14] Khan, S., Umer, R., Umer, S., \& Naqvi, S. (2021). Antecedents of trust in using social media for E-government services: An empirical study in Pakistan. Technology in Society, 64(October 2020), 101400. https://doi.org/10.1016/j.techsoc.2020.101400

[15] Kim, J., Jin, B., \& Swinney, J. L. (2009). The role of retail quality, e-satisfaction, and e-trust in the online loyalty development process. Journal of Retailing and Consumer Services, 16(4), 239-247. https://doi.org/10.1016/j.jretconser.2008.11.019

[16] Kim, Y., \& Peterson, R. A. (2017). ScienceDirect A Meta-analysis of Online Trust Relationships in E-commerce. Journal of Interactive Marketing, 38, 44-54. https://doi.org/10.1016/j.intmar.2017.01.001

[17] Konuk, F. A. (2018). The role of store image, perceived quality, trust, and perceived value in predicting consumers' purchase intentions 
towards organic private label food. Journal of Retailing and Consumer Services, 43(May), 304-310. https://doi.org/10.1016/j.jretconser.2018.04.011

[18] Luo, N., Wang, Y., Zhang, M., Niu, T., \& Tu, J. (2020). Integrating community and e-commerce to build a trusted online second-hand platform: Based on the perspective of social capital. Technological Forecasting and Social Change, 153(November 2019$), 119913$. https://doi.org/10.1016/j.techfore.2020.119913

[19] Marakanon, L., \& Panjakajornsak, V. (2017). Perceived quality, perceived risk, and customer trust affect customer loyalty to environmentally friendly electronics products. Kasetsart Journal of Social Sciences, 38(1), 24-30. https://doi.org/10.1016/j.kjss.2016.08.012

[20] Pavlou, P. A. (2003). Consumer acceptance of electronic commerce: Integrating trust and risk with the technology acceptance model. International Journal of Electronic Commerce, 7(3), 101-134. https://doi.org/10.1080/10864415.2003.11044275

[21] Rather, R. A. (2021). Monitoring the impacts of tourism-based social media, risk perception, and fear on tourist's attitudes and revisiting behavior in the wake of the COVID-19 pandemic. Current Issues in Tourism, O(0), 1-9. https://doi.org/10.1080/13683500.2021.1884666

[22] Sarkar, S., Chauhan, S., \& Khare, A. (2020). A meta-analysis of antecedents and consequences of trust in mobile commerce. International Journal of Information Management, 50(March 2019), 286-301. https://doi.org/10.1016/j.ijinfomgt.2019.08.008

[23] Sarstedt, M., Ringle, C. M., \& Hair, J. F. (2020). Handbook of Market Research. In Handbook of Market Research. https://doi.org/10.1007/9783-319-05542-8

[24] Sezgin, E., Özkan-Yildirim, S., \& Yildirim, S. (2018). Understanding the perception towards using mHealth applications in practice: Physicians' perspective. Information Development, 34(2), 182-200. https://doi.org/10.1177/0266666916684180

[25] Thaichon, P., Lobo, A., Prentice, C., \& Quach, T. N. (2014). The development of service quality dimensions for internet service providers: Retaining customers of different usage patterns. Journal of Retailing and Consumer Services, 21(6), 1047-1058. https://doi.org/10.1016/j.jretconser.2014.06.006

[26] Wang, S. W., Ngamsiriudom, W., \& Hsieh, C. H. (2015). Trust disposition, trust antecedents, trust, and behavioral intention. Service Industries Journal, 35(10), 555-572. https://doi.org/10.1080/02642069.2015.1047827

[27] Young Kim, E., \& Kim, Y. (2004). Predicting online purchase intentions for clothing products. European Journal of Marketing, 38(7), 883-897. https://doi.org/10.1108/03090560410539302

[28] Zhang, T., Tao, D., Qu, X., Zhang, X., Lin, R., \& Zhang, W. (2019). The roles of initial trust and perceived risk in the public's acceptance of automated vehicles. Transportation Research Part C: Emerging Technologies, 98(November 2018), 207-220. https://doi.org/10.1016/j.trc.2018.11.018

[29] Zhao, J. Di, Huang, J. S., \& Su, S. (2019). The effects of trust on consumers' continuous purchase intentions in C2C social commerce: A trust transfer perspective. Journal of Retailing and Consumer Services, 50(April), 42-49. https://doi.org/10.1016/j.jretconser.2019.04.014 